\title{
無反射管による喉頭原音の抽出法
}

田辺 正博*。一色 信彦**。北嶋 和智*

\section{Measurement of the Glottal Waveform by a Reflectionless Tube}

\author{
Masahiro Tanabe, Nobuhiko Isshiki and Kazutomo Kitajima
}

(Kyoto Univ.) form.

A reflectionless tube described by Sondhi is utilized to obtain the glottal wave-

The rationale of this method is that the effect of vocal-tract resonances on glottal waveform is considerably reduced by phonating into a reflectionless uniform tube.

Measurement of the transmission characteristic (frequency response) of the tube proved minimal attenuation caused by the tube.

The obtained glottal waveform in four normal subjects and in nine patients with laryngeal pathologies are reported herein and methods presently available for estimating the glottal waveform are also discussed. The glottal waveform with reflectionless tube proved to be simpler and more practical for clinical use.

\section{は じめに}

喉頭疾患の診断，および嗄声のメカニズム解明の手段のひとつに音声の分析が挙げられる。発声 された音声波形には喉頭原音（声門波形）の特徵のみならず声道の形に応じたスペクトル構造が含 まれている. 即ち, 声帯振動に伴う声門波形は声門より口唇に至る声道の形に応じた音色の変化を 受ける。より明確にいうならば，声門波形の各倍音成分 (harmonics) の振幅を $\mathrm{S}(\mathrm{f})$ ， その周波 数に打ける声道の伝達関数を $\mathrm{T}(\mathrm{f})$ とするならば, 結果として, 口前で聞かれる音声の周波数成分 の振幅 $\mathrm{P}(\mathrm{f})$ は両者 $\mathrm{S}(\mathrm{f})$ と $\mathrm{T}(\mathrm{f})$ の積となる.

$\mathrm{P}(\mathbf{f})=\mathrm{S}(\mathbf{f}) \cdot \mathrm{T}(\mathbf{f})$

これを対数 $(\mathrm{dB})$ で表せば

$20 \log _{10} \mathrm{P}(\mathrm{f})=20 \log _{10} \mathrm{~S}(\mathrm{f})+20 \log _{10} \mathrm{~T}(\mathrm{f})$ 
VOCAL CORD PULSES

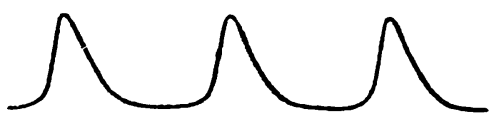

RADIATED WAVE

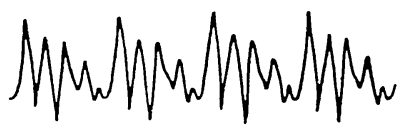

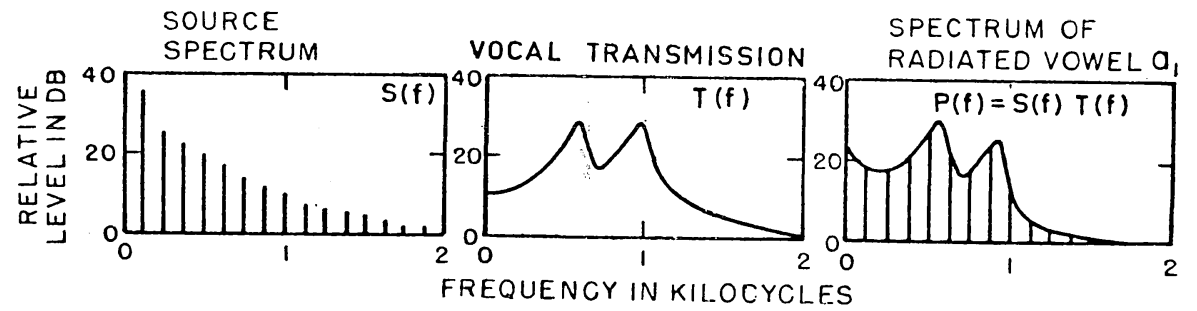

図 I：声門波，声道の伝達関数，放射音声の周波数スペクトラム。(Fant, 1960)

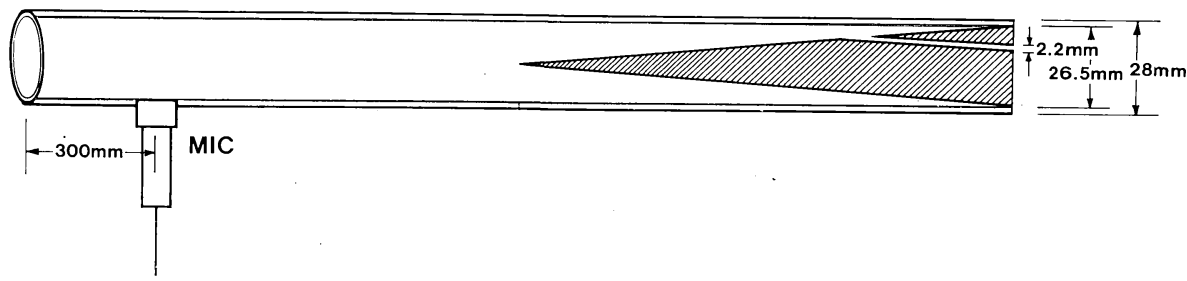

図 2 : Sondhi の無反射管

の如く和となる，乙の関係を図示すると図1のようになる．声門波は図 1 上段左に示す如く単純な 波形で，そのスペクトラムは図 1 下段左の如く一般に高い周波数ほど減衰している（減衰特性約 -12 dB/oct，鋭い三角波に似た声門波形の場合は高調波成分が強く減衰特性は緩かになる)。図 1 下段中央は声道伝達特性を示したもので, 口前音波形は上段右, その周波数スペクトラムは下段右 の如くなる $\left(\mathrm{Fant}^{1)}\right.$, 1960).

発声障害の場合, 問題になるのは声門波形であるから, できれば声道の影響をうけない声門波形 を直接抽出分析することが望ましい，今回我々は Sondhi ${ }^{21}$ （1975）の考案になる無反射管を作製 し声門波形の抽出を試みたのでその結果を報告する.

実

1. 無反射管の原理

声門で生じた比較的単純な波形（先端のなま った三角波ないし鋸歯状波）が声道断面積の急 激な変化のある所では反射される，特に声道断 端である口唇部で反射され，その反射波は声門 に帰り声門波形と重畳する。重畳した波形は再 び口唇部で反射され，さらに声門皮と重畳する ことになる。声門と反射部位（主に口唇）との
験

距離ならびに音速との関係で何個の反射波が原 波形に重畳するかが決定される。換言すれば反 射がなければ音源そのものが記録されるととに なる．理論的には断面積の変化のない声道が同 一断面積の剛性の壁をむつ無反射管に連続して いれば反射波は起らず，管のどの部分にマイク ロフォンを置いても声門波形と同じ波形が記録 される。 


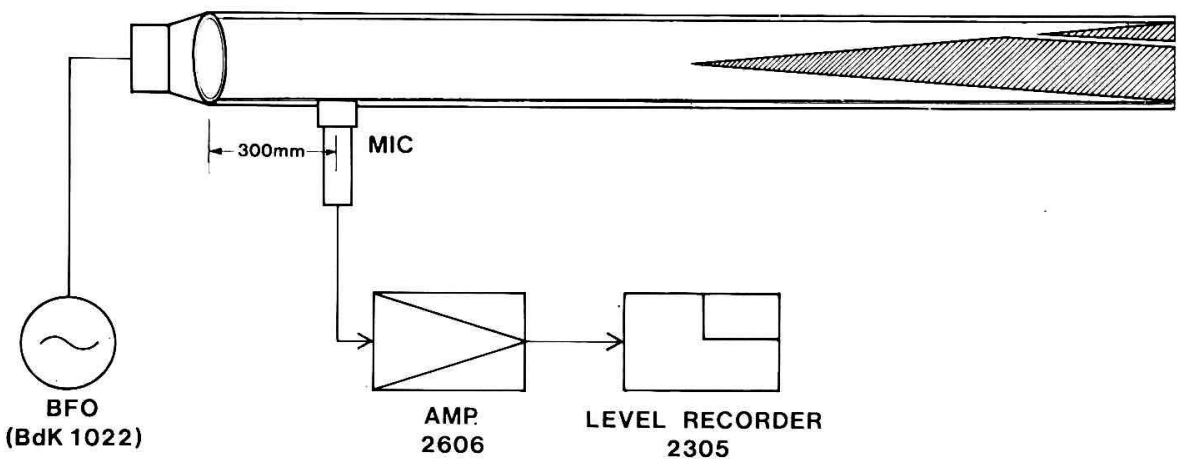

図 3 : 無反射管の周波数特性の測定

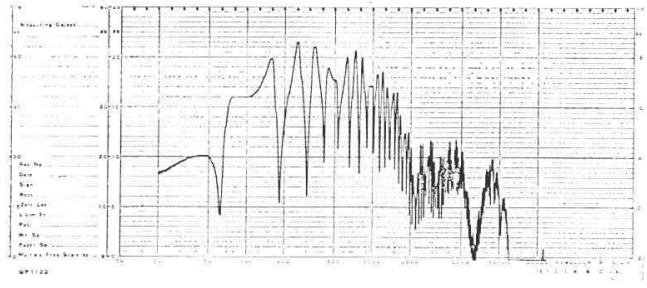

図 4：Tube の遠位端を䦗鎖した時の周波数特性

\section{2．無反射管の作製}

無反射管は Sondhi ${ }^{2)}$ （1975）の原型にもと づいて作製した。図 2 にその概略を示す，内径 $2.65 \mathrm{~cm}$, 長さ $180 \mathrm{~cm}$ 真签チニーブの一端を開

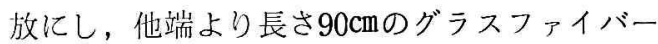
製の円錐形の楔を插入した。発声時呼気の息抜 きのため楔には内径 $0.22 \mathrm{~cm}$ のンンルを作って ある。マイクロフォンは SONY ECM-51 を用 い，無反射管の開放端より $30 \mathrm{~cm}$ の部に小孔を開 け管内に突出しない様，密着固定した。

3. 無反射管の較正

a，反射波減衰率

無反射管開放端よりパルスを出し，その反射 波の滅衰率を测定した（松下電気，音響研究所 後藤敏幸部長の協力による)。 その絬果反射波 の減衰は1/14すなわち $23 \mathrm{~dB}$ であった.

b . 無反射管の周波数特性

図 3 に実験のブロック, ダイアグラムを示

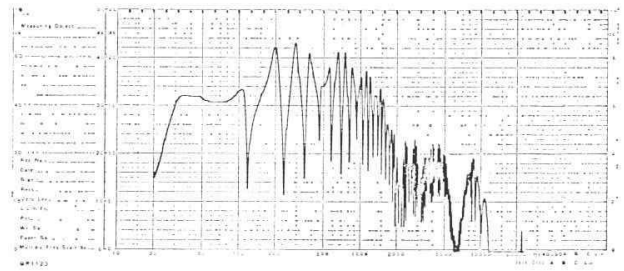

図 5：Tube の遠位端を開放した時の周波数特性

す．無反射管の開放端にスピーカーを密着，ス イープ発振器を用い, 各周波数を連続的に発振,

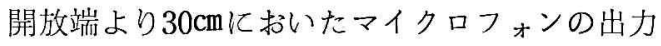
レベルをレベルレコーダーに記録, 周波数の函 数として表わした。実験の結果袏 $4 ， 5 ， 6$ に示す．図 4 は管の遠位端を閉鎖した場合，図 5 は管の遠位端を開放とした場合の周波数特性 を表わしている，図 6 は管の遠位端に図 2 に示 したグラスファイバー製の円錐形の楔を插入し た場合の結果である．無反射管での共鳴が極め てよく抑えられているのがわかる.

\section{4. 声門波形の抽出実験}

声門波形の抽出を正常音声, 病的音声につい て行った. 図 7 の如く被験者は口に Sondhi の 無反射管をくわえ，霜のとてろまで入れ，で きるだけ声道断面と無反射管内腔とがなめらか に移行する様にする．特に母音を指定しない neutral vowel, 中性母音を発声せしぬ, 図 2 亿 示した如く無反射管に挿入したマイクロフォン 


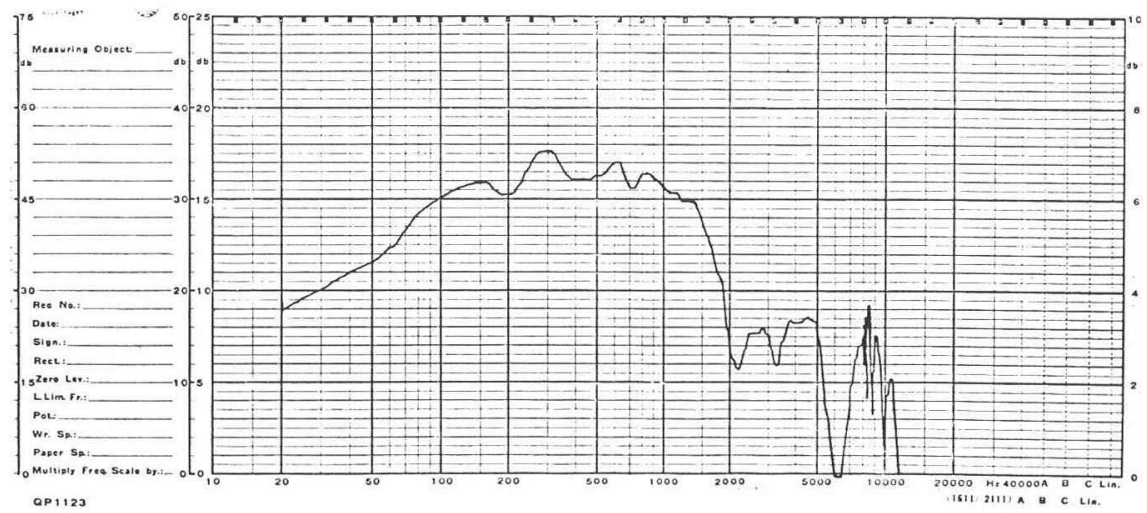

図 6：Sondhi の無反射管の周波数特性

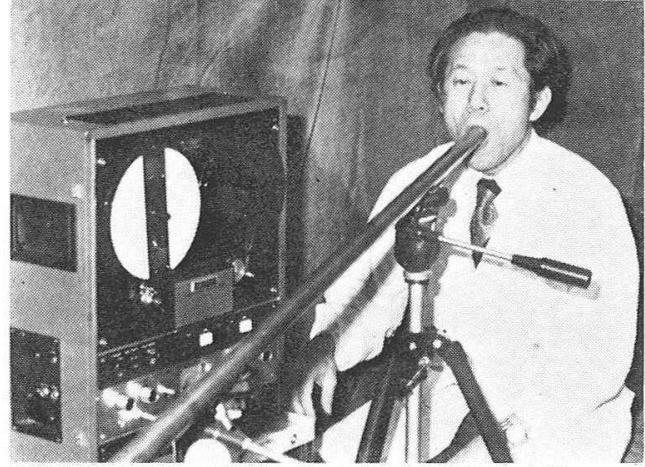

図 7 : 無反射管による声門波形抽出実験
（SONY ECM-51）より記録した。 マイクロ フォンの出力は on line でオッシロスコープ (TEXTRONIX $5103 \mathrm{~N}$ ) 飞描出, ポラロイ ドカメラ（C-5 Oscilloscope Camera）を用 い記録した．同時に抽出された声門波形をテー プレコーダー（SONY TC707MC） により記 録し，後の詳絗な分析に供する椂にした。
図 8 は喉頭疾患のない正常者で口前で銢音し た音声波形と Sondhi の無反射管により抽出 した声門波形（近似声門波形）を示したもので ある（両者は同時記録ではないので位相は対応 しない)。上段の口前音波形と比較すれば判る 如く, 無反射管で抽出された波形は単純で基本 周波数，同瞬時変動等の分析は極めて容易にな る.

正常声者 4 名（男 3 名, 女 1 名）で, 種々の 高さの発声について声門波形の抽出を行った。 結果を図 9 〜 12 に示す. いずれの case であ反 射波はよく抑えられ，単純な形の近似声門波形
果

が得られた.

図13〜18に嗄声を伴う喉頭疾患例で抽出した 声师波形を示す。図13上下は左反回神経麻痺で と屯に中等度以下の声門閉鎖不全を伴う症例， 図14上下は高度の声門閉鎖不全を伴う症例で， 抽出された声門波形は非常に不規則である。次 にポリープ様声帯の 2 症例の声阴波形を図15上 下に示す。図15下に示す例では音声は 2 重声 (Diplophonia) と表現できるむので，その声 門波形は 3 つずつがグループを成している，図 16は喉頭癌症例, 図17は男性化音声, 図18は喉 頭外傷症例で抽出された声門波形である. 


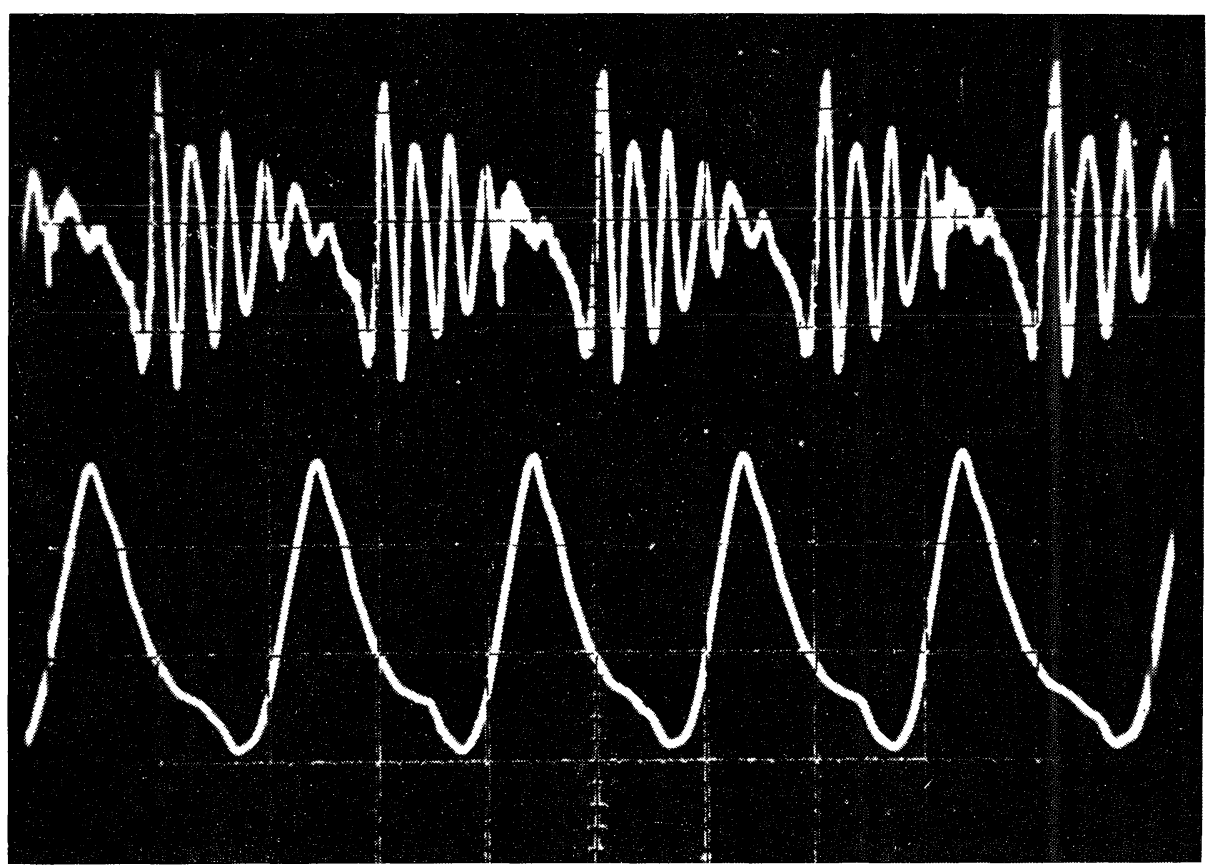

図 8：上段；口前音波形 下段；無反射管による声門波形 両者は同時記録ではないので，位相は一 致しない

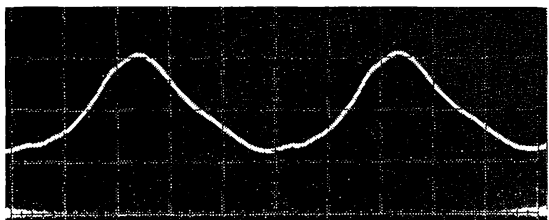

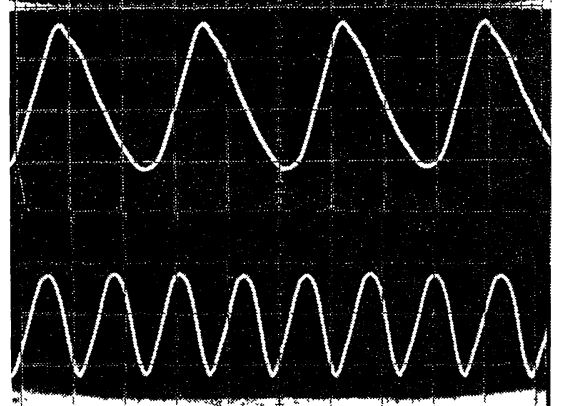

図 9 : 正常声, 男, 1 目盛：2 msec
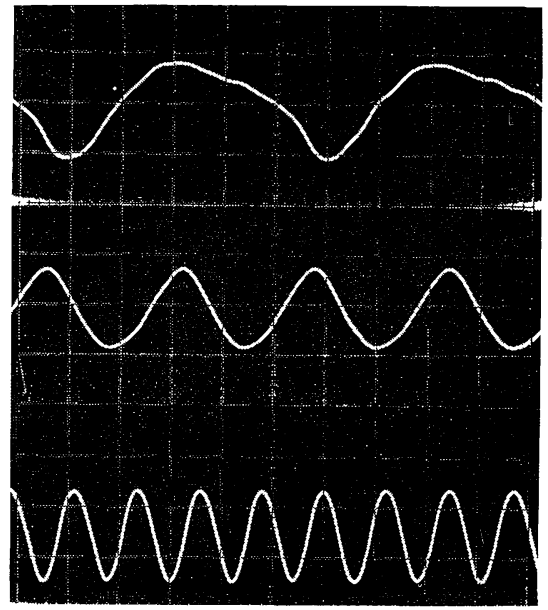

図10：正常声，男，1目盛：2 msec 


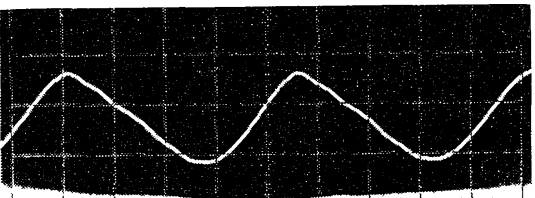

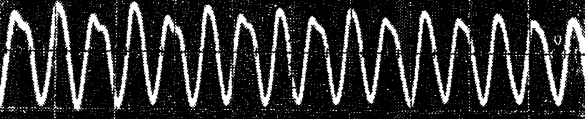
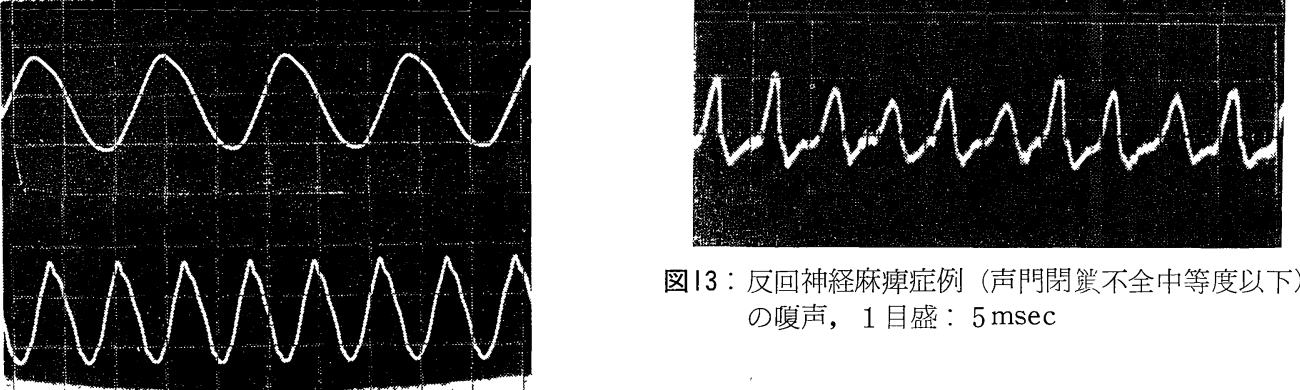

図 13：反回神経麻瘏症例（声門閉镍不全中等度以下） の腹声， 1 目盛： $5 \mathrm{msec}$

図ＩI：正常声，男，1目盛：2 msec
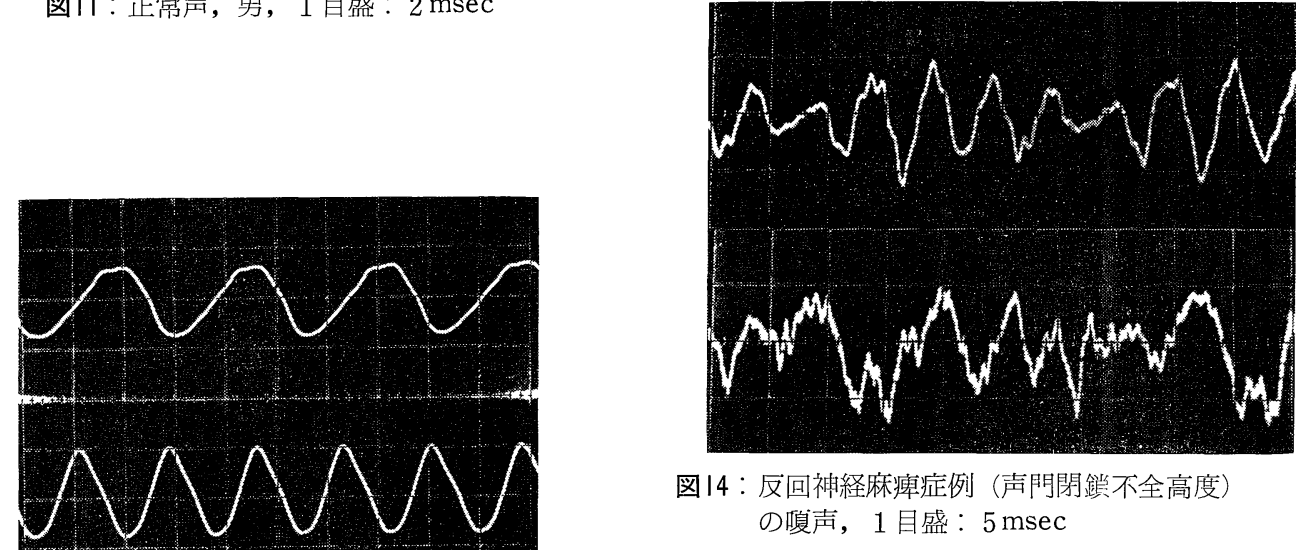

図 14：反回神経麻瘏症例（声門閉鎖不全高度） の嗄声, 1 目盛： $5 \mathrm{msec}$

\section{WWW}

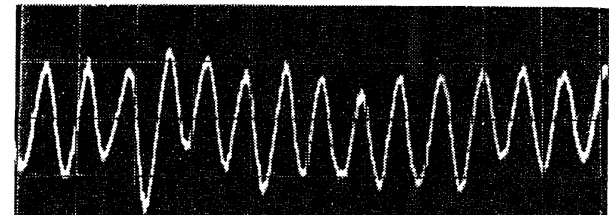

MWWWWMW

nowowownow

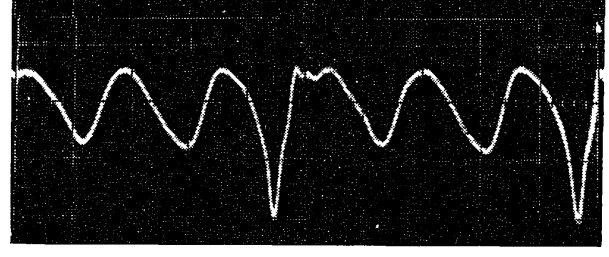

図15：ポリープ様声帯症例の嗄声, 1 目盛： $5 \mathrm{msec}$

図 12: 正常声, 女, 1 目盛: $2 \mathrm{msec}$ 


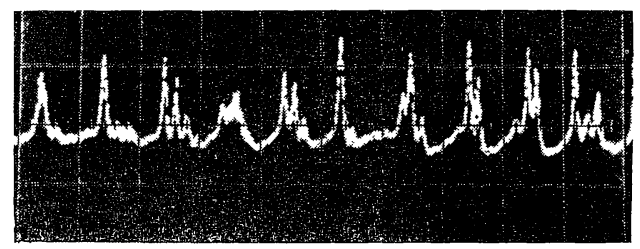

図 16：喉頭癌症例の腹声， 1 目盛： $5 \mathrm{msec}$

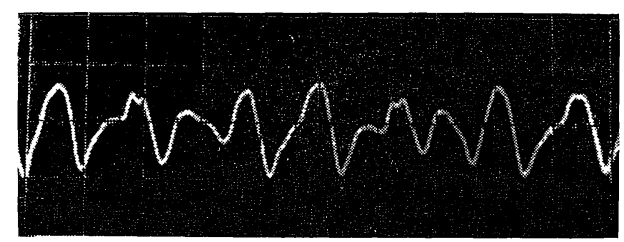

図 17：男性化音声，1目盛：5 msec

考

喉頭疾患の診断には声道の影響をうけない声 門波形を直接測定できれば理想的だが，現在の ところ技術的に困難であり，種々の間接法ない し近似法が行なわれている。

我々の今回行なった声門波形の抽出法との此 較のため現在行われている種々の方法につい て，以下簡単に検討を加える.

まず1）喉頭の高速度映画による方法ではフ ィルムを钩毎に分析するととにより声門面積の 変化は可なり正確に得られるが声門波形は声門 面積変化より推定しなければならない，2）光 電グロトグラム $\left(\right.$ Sonesson $\left.{ }^{3)}, 1960\right)$ では声 門を通過する光の強さの変化より声門面積変化 を求める，3）電気グロトグラム $\left(\mathrm{Fabre}^{4)}\right.$, 1958）は声門の開閉に伴なう電気容量変化を応 用するものである，2）3）では1）之同様に 声門波形は声門面積変化より推定されるが, 声 門面積変化自体が間接的に測定されるため得ら れる声門波は 1）の方法より信頼性が劣るとい える，しかし測定方法が 1）より簡単で実用的 だという利点がある。より実用的には4）気管 前壁音（気前音）(杉本，比企 ${ }^{5)} ， 1960 ）$ がピ ッチ抽出の目的で特に医学領域で用いられてき た。経験的には声門波形に似ており簡単で実用

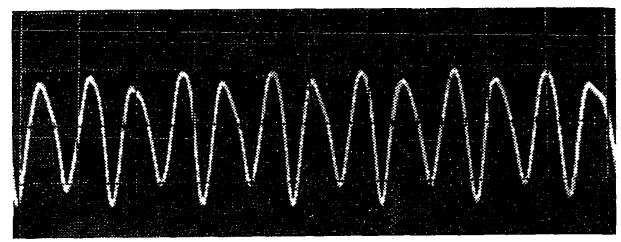

図 18：喉頭外傷例の嗄声，1目盛：5 msec

按

的だが，周波数成分に関する較正の面で定量的 に難点がある。その他に 5 ）超音波利用（金子 他 ${ }^{6}$ ，1970）。6）声門下圧の直接測定（比企 他7)，1970）などあ行なわれているが実用性と いう面で問題がある.

また最近では 7 ) 逆フィルタ一法 (Mathews et $\mathrm{al}^{8)}$ ，1961; Rothenberg9)，1973）が頻用 されている．その原理は声道の伝達関数の逆数 に相当するフィルターを通し，口前音波形より 直接，声門波形を抽出するむのである．乙の方 法には，適切なフィルターの決定が容易でない こと，患者に on-line で使用できないととな ぞの欠点があり，未だ臨床的実用段階にいたっ ていない.

今回我々の使用した Sondhi の無反射管之 7）逆フィルター法の根本的な違いは 7）が声 道の形により影響をうけた口前音波形から声道 の影響をとりのぞくのに対し，本法では最初か ら声門波形が最少のひずみで伝達される条件を 作る様にし，逆フィルターを必要としないとと である。

本実験の結果が示す様に Sondhi の無反射 管を使用することにより声門波形（㛜密には近 似声門波形）が比較的簡単に得られることがわ 
かった。

本法は嗄声のメカニズム解明，喉頭疾患の診
断に有用な手段となり得ると考える.

Sondhi の考案になる無反射管を作製，較正を行ない，喉頭原音（声門波形）の抽出に使用した．

発声障害のない正常例および嗄声を伴なう喉頭疾患例で声門波形の抽出を試みた結果，いずれの 例であ反射波はよく抑えられ単純な近似声門波が得られた。

本法は他の声門波抽出法に比し簡単な方法で近似声門波抽出が可能であり，実地臨床上きわめて 実用的であるとの結論を得た。

\section{参 考 文 献}

1) Fant, G: Acoustic theory of speech production. Mouton Co., 's-Gravenhage, 1960.

2) Sondhi, M. M. : Measurement of the glottal waveform. J. Acoust. Soc. Am. $57: 228 \sim 232$ 1975.

3 ) Sonesson, B. : On the anatomy and vibratory pattern of the human vocal folds-with special reference to a photoelectrical method for studying the vibratory movements. Acta Otolaryng. 156: 1, 1960.

4) Fabre, M. P.: Etude comparée des glottogrammes et des phonogrammes de la voix humaine. Ann. d'otolaryng. $75: 767 \sim 767$, 1958.

$5 ＼mathrm{~ ） 杉 本 利 孝 ， 比 企 静 雄 ： 気 管 外 䈉 の 振 動 に よ る 音 声 ~}$ の基本周波数の抽出. 音声の分析合成委員会資 料. $1 \sim 12,1960$.

6 ）金子敏郎，他：発声時の両側声帯面積比の経時的
変化について.日本超音波医学会講演論文集. 1970.

7) Hiki, S., Koike, Y and Takahashi, H. : Simultaneous measurement of subglottal pressure variations. J. Acoust. Soc. Am. 48 : 118 119, 1970.

8 ) Mathews, M. V., Miller, J. E. and David, E. E. : An accurate estimate of the glottal waveshape. J. Acoust. Soc. Am. $33: 843$, 1961.

9) Rothenberg, M. : A new inverse-filtering technique for deriving the glottal air flow waveform during voicing. J. Acoust. Soc. Am. 53 : 1632 1644, 1973.

原稿到着：昭和53年 4 月 7 日 別刷請求先: 田辺正博 击606 京都市左京区聖護院川原町53 京都大学医学部耳鼻咽喉科学教室 